\title{
電流規制によるクラウンエーテル共存下でのスズの 結晶電析過程における電位振動
}

\author{
根 津 弘 幸*, 金子紀男, 篠 原直行

\section{Potential Oscillations during Electrocrystallization of Tin in the Presence of Crown Ether under Galvanostatic Conditions}

\author{
Hiroyuki NEz* ${ }^{*}$, Norio KANEKO and Naoyuki SI IIXOHLRA
}

Received June 24, 1986 ; Accepted October 2, 1986

\section{1 緒 言}

電気化学システムにおけ打振動現象についての報告は

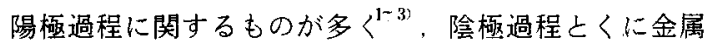
の結晶電析過程における電位振動についての報告は少な

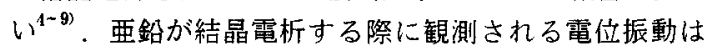
陰極表面での亜鉛イオンの濃度の周期的変化に基づ き8，また，吸着性有機物共存下に执いてスズが結晶電 析する際に観測される電位振動は陰極表面での吸着性有

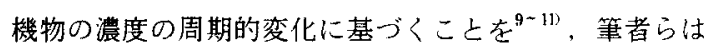
報告してきた。

プロトンを取り込んだクラウンエーテル（ジシクロヘ キシルー18一クラウンー6) は滴下水銀電極上において有 機カチオンとして $0 \mathrm{~V}$ から $-1.5 \mathrm{~V}$ の電位範用で吸着 し ${ }^{12}$ 13)，また，クラウンエーテル共存下において固体電 極上でスズが結晶電析する際, 電流一電位曲線上に限界 電流が認められた，さらに，この限界電流より高い一定 の電流密度で電解を行うよ陰極電位の振動が観測され る.

本研究は，クラウンエーテル共存下においてスズが結 晶電析する際に認められる電位振動について電気化学的 に検討したものである.

\section{2 実 験}

電流一電位曲線および電位一時間曲線の測定には北斗 電工製ポテンシオスタット・ガルバノスタット HA-310 型を使用した。電流一電位曲線は電位設定後 30 秒経過 したときの定常電流値を電位に対してプロットすること により求めた．可視スペクトルの測定には日立製ダブル ビーム分光光度計 124 型を使用した. $0.5 \mathrm{~mol} / \mathrm{dm}^{3}$ 硫酸 水溶液を基礎液とし, 電解液量は $100 \mathrm{~cm}^{3}$ とした。测 定温度は $25 \pm 1{ }^{\circ} \mathrm{C}$ し，電位は飽和カロメル電極を基準

信州大学工学部 (T380 長野市若里 500) Faculty of Engineering, Shinshu University ( 500 Wakasato, Nagano, 380) Key Words : Potential Oscillation, Electrocrystallization, Tin, Crown Ether
として測定した，陰極としては既報草と同じ前処理を 行った表面積 $10 \mathrm{~cm}^{2}$ の低炭素鋼板（日新製鋼製 $\mathrm{NCB}$ ) を，また，陽極としては金属スズ板(米山薬品製)を， それぞれ使用した。テトラフェニルホウ素酸ナトリウム 塩は半井化学薬品製特級試薬を, また, テトラブロムフェ ノールフタレインエチルエステルカリウム塩は東京化成 工業製特級試薬を，それぞ㧈使用した。実験に用いたそ の他の試薬は既報 ${ }^{9.12)}$ 上同じである.

\section{3 結果および考察}

\section{1 電位規制による電流一電位曲線}

Fig. 1 は, $0.25 \mathrm{~mol} / \mathrm{dm}^{3}$ の硫酸スズを含む基礎液に クラウンエーテルを添加した溶液について，低炭素鋼板 を陰極として求めた電流一電位曲線を示したものであ る. クラウンエーテルを添加しない場合には， $-0.45 \mathrm{~V}$

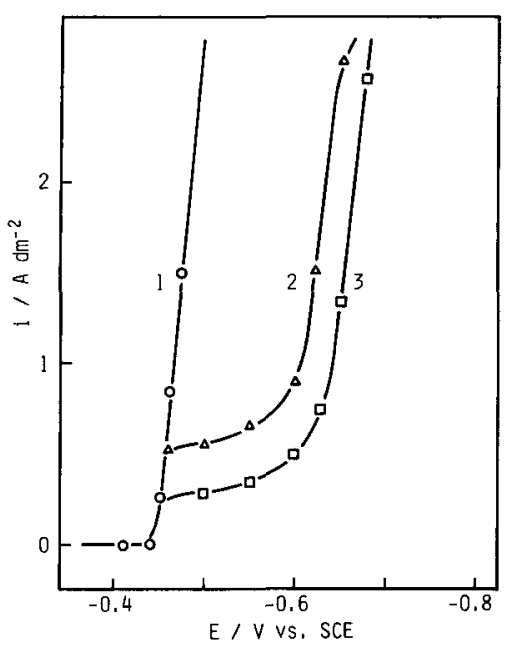

Fig. 1 Current-potential curves of tin (II)ion under potentiostatic conditions

(1) $: 0.5 \mathrm{~mol} / \mathrm{dm}^{3} \mathrm{H}_{2} \mathrm{SO}_{4}+0.25 \mathrm{~mol} / \mathrm{dm}^{3} \mathrm{SnSO}_{4}$

(2) : (1) $+5 \times 10^{-3} \mathrm{~mol} / \mathrm{dm}^{3}$ crown ether

(3) : (1) $+5 \times 10^{-3} \mathrm{~mol} / \mathrm{dm}^{3}$ crown ether (stirring) 
よりスズイオンの還元に基づく電流値の急激に上昇 する曲線となった(Fig. 1の1)，一方, $5 \times 10^{-3} \mathrm{~mol} /$ $\mathrm{dm}^{3}$ のクラウンエーテルを添加した場合には，0.5 $\mathrm{A} / \mathrm{dm}^{2}$ に限界電流を与える曲線となった。 ( Fig. 1 の2).Fig. 1 のは、クラウンエーテルを添加した 溶液について，溶液を強制的にかくはんしながら求 めた電流－電位曲線を示したものである。このよう に，溶液をかくはんした場合においても限界電流

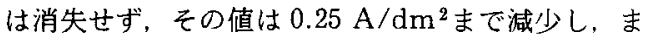
た，最終上昇の電位も負側に移行した，溶液をかく はんすることによってスズイオンの䋠給が促進され るにもかかわらず限界電流が減少することは, 溶液 をかくはんすることによってクラウンエーテルの補 給る促進され, その結果, クラウンエーテルの吸着 に基づく抑制勃果がより顕著に現われたことを示唆 する. したがって, 上記の限界電流は, 添加したク ラウンエーテルが電極上に吸着することにより ${ }^{12.13}$ スズイオンの還元に対する不均一反応過電圧 ${ }^{15)}$ が 生じたために現われるものと考えられる.

\section{2 電流規制による電位一時間曲線}

$0.25 \mathrm{~mol} / \mathrm{dm}^{3}$ の硫酸スズを含む基礎液について 電流規制による電解を行うと, 陰極電位は, 上記溶 液について求めた電流一電位曲線 (Fig. $1 の 1)$ 上 の電解電流密度に対応する電位で一定となった。

Fig. 2 は，硫酸スズを含む基礎液に $5 \times 10^{-3} \mathrm{~mol} /$ $\mathrm{dm}^{3}$ のクラウンエーテルを添加した溶液について 求めた電位一時間曲線を示したものである。クラウ ンエーテルを添加して求めた電流一電位曲線 (Fig. 1の2) 上に現われる限界電流上り低い $0.3 \mathrm{~A} / \mathrm{dm}^{2}$ で電解した場合には, 電位は $-0.46 \mathrm{~V}$ で一定となっ た (Fig. 2 の).ところが, 限界電流より高い 0.75 , $1.0 \mathrm{~A} / \mathrm{dm}^{2}$ で電解した場合には Fig. 2 の 2,3 に示 すように, 一定の誘導時間を経たのち, 電位振動が 観測された。1.0 A/dm² で電解した場合の電位振 動の振幅は $150 \mathrm{mV}(-0.49 \sim-0.64 \mathrm{~V})$, 周期は平均 3.6 分であり，時間が経過するにしたがって周期が 長くなる傾向が認められた (Fig. 2 の 3). 電位振 動の正側の電位 $(-0.49 \mathrm{~V})$ は、クラウンエーテル を添加しない溶液について求めた電流一電位曲線 (Fig. 1の1) 上の $1.0 \mathrm{~A} / \mathrm{dm}^{2}$ に対応する電位に，また， 負側の電位 $(-0.64 \mathrm{~V})$ は.クラウンエーテルを添加し て求めた電流一電位曲線 (Fig. 1 の2) 上の $1.0 \mathrm{~A} / \mathrm{dm}^{2}$ に対応する電位に，それぞれほぼ一致した，一方，2.0 $\mathrm{A} / \mathrm{dm}^{2}$ で電解した場合には電位は $-0.65 \mathrm{~V}$ 付近で一 定となった(Fig. 2の 4).

Fig. 3 は, $0.25 \mathrm{~mol} / \mathrm{dm}^{3}$ の硫酸スズおよび $5 \times 10^{-3}$ $\mathrm{mol} / \mathrm{dm}^{3}$ のクラウンエーテルを含む基礎液について, 溶液を強制的にかくはんしながら電流密度 $1.0 \mathrm{~A} / \mathrm{dm}^{2}$

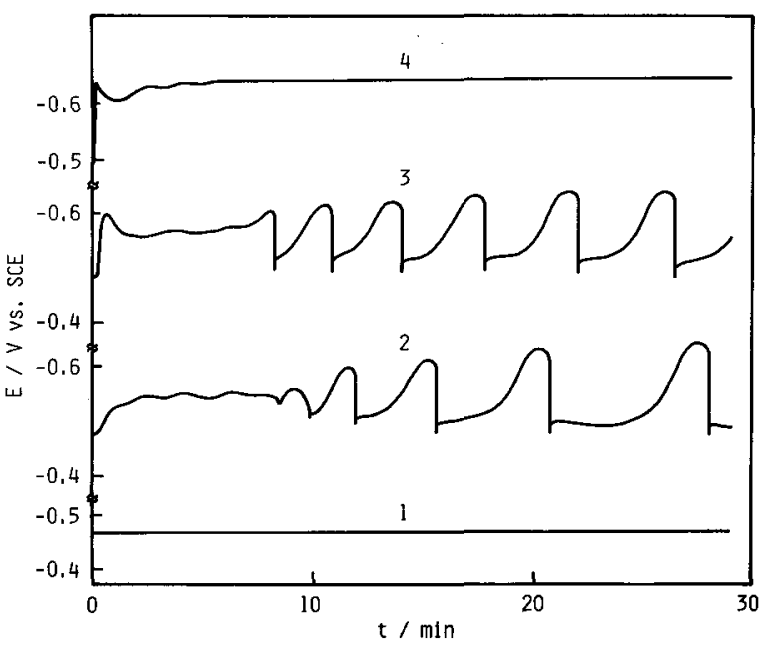

Fig. 2 Potential-time curves during electrocrystallization of tin under galvanostatic conditions $\left(0.5 \mathrm{~mol} / \mathrm{dm}^{3} \quad \mathrm{H}_{2} \mathrm{SO}_{4}+0.25 \mathrm{~mol} / \mathrm{dm}^{3} \quad \mathrm{SnSO}_{4}+5 \times\right.$ $10^{-3} \mathrm{~mol} / \mathrm{dm}^{3}$ crown ether)
(1) : $0.3 \mathrm{~A} / \mathrm{dm}^{2}$,
(2) : $0.75 \mathrm{~A} / \mathrm{dm}^{2}$,
(3) $: 1.0 \mathrm{~A} / \mathrm{dm}^{2}$,
(4) $: 2.0 \mathrm{~A} / \mathrm{dm}^{2}$

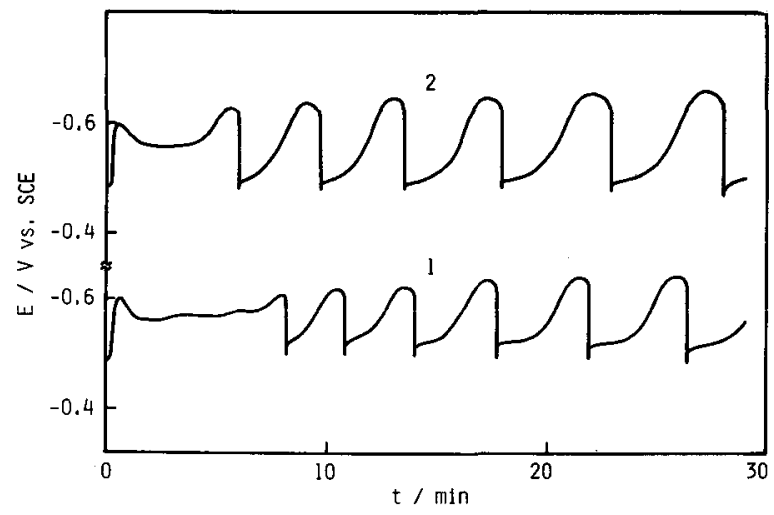

Fig. 3 Effect of stirring on the potential oscillation $\left(0.5 \mathrm{~mol} / \mathrm{dm}^{3} \mathrm{H}_{2} \mathrm{SO}_{4}+0.25 \mathrm{~mol} / \mathrm{dm}^{3} \mathrm{SnSO}_{4}+5 \times\right.$ $10^{-3} \mathrm{~mol} / \mathrm{dm}^{3}$ crown ether, current density; 1.0 $\mathrm{A} / \mathrm{dm}^{2}$ )

(1) : no stirring, (2): stirring

で電解して求めた電位一時間曲線を示したものである. なお，溶液をかくはんせずに求めた曲線もあわせて示し た。溶液をかくはんした場合においても電位振動が観測 され(Fig. 3の2), 溶液をかくはんしない場合に観測さ れる電位振動 (Fig. 3の1) に比べて誘導時間は短くな り，また，振幅は大きくなった。

\section{3 電析スズ中へのクラウンエーテルの共析}

スズの結晶電析過程に㧊いて電析スズの中にクラウン エーテルが共析するか不かについて哈味するために，電 
析スズを陽極溶出させ，この溶出液についてクラウン エーテルの有無を検討した. 電析スズは, $0.25 \mathrm{~mol} / \mathrm{dm}^{3}$ の硫酸スズおよび $5 \times 10^{-3} \mathrm{~mol} / \mathrm{dm}^{3}$ のクラウンエーテ ルを含む基礎液について, 電流密度 $1.0 \mathrm{~A} / \mathrm{dm}^{2}$ で 30 分間電解して得た。

溶出液に第四アンモニウムイオンの沈㳀試薬であるデ トラフェニルホウ素酸 (TPB) ナトリウム水溶液を添加 すると白色沈筑が生じた.この沈祋は、プロトンを取り込 み有機カチオンとなったクラウンエーデ ${ }^{12.13)}$ 上 TPB アニオンが反妋して生じたイオン会合性の沈澱であると 考えられる. また, 溶出液に第四アンモ二ウムイオンと イオン会合体を生成するテトラブロムフェノールフタレ

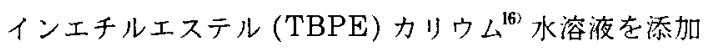
し，クロロホルムにより抽出して可視スペクトルを求ぬ た.そのスペクトルは $607 \mathrm{~nm}$ にクラウンエーテル・ TBPE 会合体の吸収に基づく極大を与え，検量線法に より定量すると電析スズの中には $0.02 \mathrm{wt} \%$ クラウン エーテルが共析していることが判明した.

\section{4 陰極電位の周期的変化}

ポリオキシエチレンアルキルアミンおよびジフェニル アミンークロトンアルデヒド反応物共存下においてスズ が結晶電析する際に観測される電位振動は, 吸脱着に基 ラく電極表面での反応物濃度の周期的な変化により生ず ることを報告してきだ、また，吸着性有機物を含まな いアルカリ性水溶液から要鉛が結晶電析する際に観測さ れる電位振動は, 周期的に発生する水素気泡のかくはん 効果に基づいて亜鉛イオンの表面濃度が周期的に変化す るこよにより生ずるものであり ，溶液を強制的にかく はんすると電位振動は消失し，電位は一定上なる。

ところが，本実験においては，クラウンエーテルの吸 着する電位範囲内 $(0 \sim-1.5 \mathrm{~V})^{\mathrm{l})}$ に拉いて電位振動が 観测 $(-0.49 \sim-0.64 \mathrm{~V})$ されており（Fig. 2の2，3），ま た, 前述 (3.3) のごとく, 電析スズの中にはクラウンエー テルが共析していた．さらに，溶液を強制的にかくはん した場合においても電位振動が観測され（Fig.3の2), 水素気泡の発生は認められなかった。したがって，本実
験において観測される陰極電位の周期的変化はクラウン エーテルの吸着上電析スズ中へのクラウンエーテルの共 析に基づくクラウンエーテルの表面濃度の周期的な変化 により生ずるものよ考えられる。またここのような電位 振動が観測される場合，電析スズの表面には八角錐状の 結晶とその先端部に電流方向に成長する正方柱状の結晶 が観測され，X 線回折図においては (101) と (112) 面の 回折線が認められた。

現在, 電析スズの結晶形態の観察結果を考虑の上, 唅 極電位が周期的に振動するまでの誘導時間, 振動の正側 および負側の電位，振動の周期上振幅などに及ぼす諸因 子について検討中である.

\section{文 献}

1) J. Wojtowicz, "Modern Aspects of Electrochemistry", ed. by J.O'M. Bockris and B. E. Conway, No. 8, p. 47, Plenum Press, New York (1972).

2) G. Nicolis and J. Portnow, Chem. Rev., 73, 365 (1973).

3) U. F. Franck, Angew. Chem. Int. Ed. Engl., 17, 1 (1978).

4）林忠夫，石田武男，金属表面技術，10，26 (1959).

5）士肥信康，高鳲四郎，金属表面技術，13，515 (1962).

6) M. Clarke and J. A. Bernie, Electrochim. Acta, 12, 205 (1967).

7) F. W. Schlitter, G. Eichkorn und H. Fischer, Electrochim. Acta, 13, 2063 (1968).

8）根津弘幸，篠原直行，金子紀男，金属表面技術，36，286 (1985).

9)根津弘幸，金子紀男，篠原直行，電気化学，54，173 (1986)

10）金子紀男, 根津弘幸, 篠原直行, 電気化学, 50, 959 (1982)

11）金子紀男，根津弘幸，篠原直行，青山隆至，電気化学，53， 834 (1985)

12）根津弘幸, 金子紀里, 電気化学, 48, 31 (1980).

13）金于紀男，根津塴幸，電気化学, 49, 752 (1981).

14）根津弘幸，金千紀男，筬原俻行，金属表西技術，31，244 (1980).

15) K. J. Vetter, "Electrochemical Kinetics", p. 244, Academic Press, New York (1967).

16）本水昌一, 岩知道正。相栄恭一，ぶんせき，1980，234. 